\title{
Determinasi Diri Siswa Berkebutuhan Khusus di Sekolah Inklusi: Tinjauan Sistematis
}

\author{
Nerinda Rizky Firdaus \\ Program Studi Magister Sains, Fakultas Psikologi, Universitas Airlangga, Surabaya
}

Abstrak. Penelitian ini bertujuan untuk mengidentifikasi keadaan determinasi diri siswa di sekolah inklusi, faktor yang memengaruhinya, dan strategi untuk meningkatkan determinasi diri siswa. Penelitian ini merupakan sebuah tinjauan sistematis. Pencarian dilakukan pada enam basis data elektronik, yaitu ProQuest, SAGE Journals, SpringerLink, ERIC, Emerald, dan ScienceDirect. Kriteria pencarian literatur adalah artikel jurnal berbahasa Inggris yang telah berstatus peer-reviewed dan diterbitkan sejak 2009 yang dapat diunduh dalam versi lengkap, serta memberikan informasi yang relevan mengenai kondisi determinasi diri siswa di sekolah inklusi. Hasil penelitian ini adalah keadaan determinasi diri siswa memiliki perbedaan yang signifikan antara siswa berkebutuhan khusus dan siswa tanpa kebutuhan khusus di sekolah inklusi. Faktor yang memengaruhi determinasi diri siswa adalah guru, keluarga, sekolah, dan hubungan sosial di sekolah. Determinasi diri secara signifikan dapat memprediksi kualitas hidup siswa. Strategi yang digunakan untuk meningkatkan determinasi diri siswa dapat digolongkan menjadi tiga, yaitu dari sisi akademik atau memodifikasi strategi belajar, dari sisi sekolah inklusi untuk memperkaya peluang, dan membangun hubungan sosial di sekolah.

Kata kunci: determinasi diri, berkebutuhan khusus, pendidikan khusus, sekolah inklusi

\section{Self-Determination of Special Needs' Students in Inclusive School: A Systematic Review}

Abstract. This study aimed at identifying the state of students' self-determination in inclusive schools, the factors that influenced them and the strategies to increase their self-determination. This is a systematic review research. The literature searches were conducted on six electronic basis data, namely ProQuest, SAGE Journals, Springer Link, ERIC, Emerald, and ScienceDirect. Literature search criteria were peer-reviewed English-language journal articles published in 2009 that can be downloaded in full version, and provide relevant information about the conditions of student self-determination in an inclusive school. The findings show that the state of students' self-determination significantly different between students with special needs and students without special needs in inclusive schools. The influencing factors to the student self-determination are teacher, family, school, and social relations in school. Self-determination can significantly predict students' quality of life. The strategy was then designed to increase student self-determination could be classified into three, namely from the academic side or modifying learning strategies, from the side of inclusive schools to enrich opportunities, and building social relationships in schools.

Keywords: inclusive school, self determination, special education, special needs

Korespondensi: Nerinda Rizky Firdaus Email: nerinda.rizky.firdaus-2018@psikologi.unair.ac.id 
Sejumlah besar penelitian internasional yang telah dilakukan selama tiga dekade terakhir menunjukkan pentingnya determinasi diri dalam pendidikan (Seong et al., 2019). Determinasi diri adalah kunci utama dari keberhasilan pendidikan untuk semua siswa, baik siswa tanpa kebutuhan khusus maupun siswa berkebutuhan khusus. Determinasi diri meningkatkan kesempatan bagi siswa untuk mendapatkan prestasi akademik yang tinggi saat di sekolah, berhasil dalam pekerjaan dan menjadi terlibat dalam komunitas di masa dewasa. Siswa dengan beragam kemampuan harus memperoleh kapasitas, kemampuan, dan peluang untuk menentukan keputusan dalam kehidupannya sendiri (Tichá et al., 2018).

Wehmeyer (2005) mendefinisikan determinasi diri sebagai tindakan atas kehendak yang memungkinkan individu untuk bertindak sebagai agen penyebab utama atau agen kausal (causal agent) dalam kehidupannya untuk mempertahankan atau meningkatkan kualitas hidup. Wehmeyer dan Little (2013) menyebut agen kausal sebagai individu yang bertindak dengan tujuan membuat pengaruh untuk mencapai perubahan. Wehmeyer mengonseptualisasikan determinasi diri berdasarkan pada fungsi perilaku individu dalam bertindak sebagai agen kausal dalam kehidupannya yang memiliki empat karakteristik penting, yaitu: (a) fungsi otonomi, (b) regulasi diri, (c) pemberdayaan psikologis, dan (d) realisasi diri (Wehmeyer \& Field, 2007).
Determinasi diri mengindikasikan kebutuhan dasar individu yang mencakup kompetensi, keterkaitan, dan otonomi (Weinstein \& Ryan, 2011).

Determinasi diri telah dikaitkan dengan perbaikan dalam tujuan, pencapaian, dan hasil akademik (Konrad et al., 2007; Lee et al., 2010). Selain itu, determinasi diri juga membuat hasil transisi siswa yang lebih positif, termasuk manfaat dalam pekerjaan dan kehidupan bermasyarakat (Seong et al, 2019; K. Shogren, Wehmeyer, et al, 2015). Determinasi diri juga dapat meningkatkan kualitas hidup dan kepuasan hidup (Lachapelle et al, 2005; K. Shogren et al., 2006). Sebuah studi merekomendasikan pentingnya determinasi diri sebagai praktik yang efektif untuk mencapai perbaikan dalam hasil pascasekolah dan transisi sekolah (Cobb et al., 2009; Test et al, 2009).

Determinasi diri siswa berkebutuhan khusus diakui sebagai praktik terbaik dalam pendidikan dan transisi siswa (Seong et al., 2015; Shogren, 2013). Determinasi diri sebagai konstruk psikologis terkait dengan kinerja individu yang sukses dan kehendak pribadi, khususnya berkenaan dengan kebutuhan khusus (Wehmeyer \& Field, 2007). Determinasi diri dikaitkan dengan hasil akademik, sosial, dan dewasa yang positif untuk pemuda dengan berbagai berkebutuhan khusus (Fowler et al., 2007). Membangun ketahanan dan keterampilan determinasi diri seperti penetapan tujuan dan evaluasi diri 
merupakan salah satu sarana meningkatkan prestasi belajar siswa berkebutuhan khusus, khususnya dari latar belakang yang berpenghasilan rendah (Walker et al, 2011). Orang tua, guru, dan teman sebaya berpotensi memainkan peran penting yang mendukung determinasi diri siswa berkebutuhan khusus (Tichá et al, 2018).

Akan tetapi, siswa berkebutuhan khusus memiliki peluang yang lebih kecil dalam mendapatkan keterampilan, pengetahuan, sikap, serta keyakinan dalam menentukan berbagai hal di hidupnya. Siswa berkebutuhan khusus juga kurang dilatih untuk memiliki kontrol atas hidupnya sendiri (Tichá et al., 2018). Kurangnya kesempatan siswa dalam membuat pilihan secara keseluruhan adalah area yang berkembang dalam sistem inklusif. Praktisi yang berpengalaman akan menyadari bahwa pemilihan keputusan siswa dibatasi di sekolah inklusi saat melibatkan siswa berkebutuhan khusus. Di sisi lain, penentuan pilihan adalah komponen penting dari determinasi diri untuk meningkatkan perilaku dan motivasi siswa. Kesempatan untuk menentukan pilihan merupakan hal penting untuk pengembangan determinasi diri siswa (Kurth et al., 2015).

Siswa yang rendah dalam determinasi diri biasanya memiliki masalah dengan motivasi intrinsiknya karena tidak mendapatkan motivasi ekstrinsik, kurang menunjukkan keterampilan yang diperlukan untuk menyelesaikan tugas, dan memiliki nilai yang kurang memuaskan (Legault \& Inzlicht, 2013; Weinstein \& Ryan, 2011). Kurangnya karakteristik dan keterampilan terkait dengan determinasi diri dapat menyebabkan siswa mengalami kegagalan akademik dan ketidakterikatan pada sekolah. Hal ini dapat menyebabkan siswa keluar dari sekolah sebagai kegagalan yang berkelanjutan. Menurut Nota et al. (2007) siswa dengan tingkat defisiensi intelektual yang berat menunjukkan determinasi diri, kualitas hidup, dan kemampuan sosial yang rendah.

Berdasarkan paparan data dan penjelasan mengenai determinasi diri siswa dengan dan tanpa kebutuhan khusus dari penelitian-penelitian sebelumnya, menarik untuk diteliti lebih lanjut keadaan, hasil, faktor, dan strategi untuk meningkatkan determinasi diri siswa di sekolah inklusi. Oleh sebab itu, untuk mendapatkan gambaran tentang determinasi diri ini, tinjauan sistematis (systematic reviews) relevan sekali digunakan. Tinjauan sistematik menyediakan sarana untuk memahami sejumlah besar informasi ilmiah yang sering kali dikutip dan berpengaruh. Metode ini menjadi pilihan utama karena memiliki potensi besar untuk menginformasikan praktik dan kebijakan publik. Sementara, penelitian-penelitian yang mengeksplorasi pertanyaan yang sama sering menemukan hasil yang beragam atau bahkan saling bertentangan yang disebabkan oleh berbagai faktor (Siddaway et al., 2019). Menurut Siddaway et al. (2019), tinjauan 
sistematik merupakan sarana kritis untuk mengklarifikasi apakah temuan penelitian penting secara bermakna ditiru karena sifatnya yang metodis, komprehensif, transparan, dan dapat ditiru, yang bertujuan meminimalkan subjektivitas dan bias. Dengan demikian, melalui tinjauan sistematis gambaran objektif dan komprehensif tentang determinasi diri siswa sekolah inklusi bisa diungkap secara kritis dengan mengklarifikasi hasil penelitian-penelitian sebelumnya.

Tinjauan sistematis sendiri merupakan jenis tinjauan literatur khusus yang melibatkan proses pencarian sistematis untuk menemukan semua karya yang relevan, baik diterbitkan maupun tidak, yang membahas satu atau lebih pertanyaan penelitian, serta presentasi sistematis dan sintesis dari karakteristik dan temuan hasil pencarian itu (Siddaway et al, 2019). Tinjauan sistematis sendiri bertujuan untuk secara komprehensif menemukan dan menyintesis penelitian yang mengandung pertanyaan-pertanyaan tertentu (Littell et al, 2008).

Sebagaimana ditegaskan Petticrew dan Roberts (2006), bahwa tinjauan sistematis dilakukan di antaranya adalah ketika gambaran umum dari bukti dalam bidang topik tertentu diperlukan untuk mengarahkan upaya penelitian di masa depan, dan ketika gambaran yang akurat tentang penelitian masa lalu dan penelitian metodologi masa lalu diperlukan untuk mempromosikan pengembangan metodologi baru. Hasil dari tinjauan sistematis ini akan menjadi bukti yang memberikan gambaran penting dan akurat bagi penelitianpenelitian mendatang tentang determinasi diri siswa dalam hal: (a) masalah penelitian, (b) pengembangan metodologi penelitian, serta (c) kepentingan-kepentingan pragmatis intervensi psikologis bagi siswa-siswa sekolah inklusi.

Berdasarkan karya-karya publikasi yang relevan dengan masalah determinasi diri siswa di sekolah inklusi, melalui tinjauan sistematis penelitian ini ingin mengungkap gambaran tentang keadaan, hasil, faktor, dan strategi peningkatan determinasi diri siswa di sekolah inklusi secara sistematis dan sintesis. Menurut peneliti, tinjauan sistematis terhadap determinasi diri siswa masih jarang dilakukan, sedangkan gambaran objektif tentang determinasi diri siswa di sekolah-sekolah inklusi dibutuhkan dalam menentukan langkahlangkah intervensi atau pengembangan, dan menjadi dasar bagi penelitian-penelitian mendatang.

\section{Metode}

Tinjauan sistematis ini dilakukan melalui beberapa tahap (Petticrew \& Roberts, 2006), yakni: (1) Menentukan dengan jelas pertanyaan yang ingin dijawab; (2) Menentukan jenis studi yang perlu ditemukan untuk menjawab pertanyaan; (3) Melakukan pencarian literatur yang komprehensif untuk menemukan studi tersebut; (4) Menyaring hasil pencarian tersebut, yaitu menyaring studi yang diambil, 
memutuskan mana yang tampak seolah-olah mereka sepenuhnya memenuhi kriteria inklusi, dan dengan demikian memerlukan pemeriksaan yang lebih rinci, dan mana yang tidak; (5) Menilai studi yang dimasukkan secara kritis; (6) Menyintesis studi dan menilai heterogenitas di antara temuan-temuan studi; dan (7) Melakukan diseminasi temuan-temuan tinjauan.

\section{Pencarian literatur}

Penelitian ini merupakan sebuah tinjauan sistematis yang bertujuan menggambarkan hasil-hasil penelitian yang terkait dengan determinasi diri siswa di sekolah inklusi, khususnya tentang keadaan, prediktor, hasil, dan strategi untuk meningkatkan determinasi diri siswa di sekolah inklusi. Setelah menentukan pertanyaan-pertanyaan penelitian dan studi yang ingin ditemukan, pencarian pada basis data elektronik dilakukan pada bulan September 2019. Pencarian literatur ini dilakukan untuk mengidentifikasi artikel jurnal berbahasa Inggris yang telah berstatus peer-reviewed dan diterbitkan dalam 10 tahun terakhir (2009 - 2019) yang dapat diunduh dalam versi lengkap, serta memberikan informasi yang relevan mengenai kondisi determinasi diri siswa di sekolah inklusi. Pencarian dilakukan secara komprehensif dan disertai proses penyaringan melalui kriteria inklusif.
Sebagaimana penjelasan (Èablová et al., 2017), sumber data primer dan paling penting bagi tinjauan sistematis adalah basis data elektronik yang diakses melalui perpustakaan universitas. Basis data elektronik yang digunakan dalam pencarian artikel adalah ProQuest, SAGE Journals, SpringerLink, ERIC, Emerald, dan ScienceDirect. Kata kunci yang digunakan untuk mencari artikel penelitian yang relevan adalah "student", "self determination", dan "inclusive school". Kata kunci tersebut dipilih karena kata kunci tersebut memunculkan paling banyak artikel jurnal dibandingkan beberapa kata kunci lain.

Kriteria inklusi yang ditetapkan dalam penelitian ini adalah artikel-artikel jurnal yang memiliki rancangan mengukur dan menggambarkan pengalaman, faktor dan hasil dari determinasi diri siswa; melibatkan siswa yang bersekolah di sekolah inklusi sebagai subjek penelitian; dan bukan merupakan penelitian dengan metode metaanalisis, tinjauan sistematis maupun penelitian psikometri mengenai alat ukur determinasi diri. Artikel-artikel yang memenuhi kriteria eksklusi penelitian ini adalah artikel jurnal yang sudah melewati proses peer-reviewed, termasuk dalam edisi terbitan dari tahun 2009 sampai dengan 2019, dan ditulis dengan teks lengkap serta berbahasa Inggris.

\section{Analisis data}

Sebagai langkah menilai studi secara kritis, artikel yang ditemukan dalam pencarian 
diperiksa ulang untuk menentukan kesesuaiannya dengan tujuan tinjauan sistematis ini melalui analisis abstrak terlebih dahulu. Abstrak yang tidak memberikan detail informasi yang relevan akan memerlukan pemeriksaan menyeluruh untuk mengetahui relevansi artikel sebelum digunakan dalam penelitian ini. Data dikumpulkan dari artikel teks lengkap yang dianggap relevan dengan tujuan peninjauan, termasuk mencermati kualitas metodologi yang diterapkan. Proses seleksi data dilakukan dengan mengidentifikasi nama penulis dan tahun terbit artikel, judul, tujuan penelitian, ukuran sampel, desain metode, alat ukur, dan hasil penelitian.
Melalui ekstraksi data, hasil akhir dari analisis data ini berupa sintesis studi dan penilaian terhadap heterogenitas di antara temuan-temuan studi. Adapun langkah terakhir dari tinjauan sistematis ini adalah diseminasi temuan-temuan tinjauan yang dipaparkan dalam tabel ringkasan temuan.

\section{Hasil}

Berdasarkan kriteria inklusi dan eksklusi yang telah ditetapkan, sebanyak delapan artikel jurnal telah diidentifikasi memenuhi kriteria inklusi dan dianggap relevan dengan tujuan penelitian untuk merangkum fakta mengenai determinasi diri siswa di sekolah inklusi.

\section{Tabel 1}

Strategi Pencarian Literatur

\begin{tabular}{lcccc}
\hline & & \multicolumn{2}{c}{ Kriteria inklusi } & \\
\cline { 3 - 4 } $\begin{array}{l}\text { Basis data } \\
\text { elektronik }\end{array}$ & $\begin{array}{c}\text { Hasil } \\
\text { pencarian }\end{array}$ & $\begin{array}{c}\text { Artikel jurnal teks } \\
\text { lengkap dan peer- } \\
\text { reviewed dari tahun } \\
2009\end{array}$ & $\begin{array}{c}\text { Berdasarkan } \\
\text { abstrak, metode, dan } \\
\text { isi yang sesuai }\end{array}$ & $\begin{array}{c}\text { Total artikel } \\
\text { yang } \\
\text { digunakan }\end{array}$ \\
\hline ProQuest & 810 & 26 & 0 & 0 \\
SAGE journals & 56 & 31 & 3 & 3 \\
SpringerLink & 82 & 14 & 1 & 1 \\
ScienceDirect & 14 & 7 & 0 & 0 \\
ERIC & 49 & 6 & 4 & 4 \\
Emerald & 32 & 4 & 0 & 0 \\
Total & 1,043 & 88 & 8 & 8 \\
\hline
\end{tabular}

Berdasarkan Tabel 1 dapat diketahui bahwa proses pencarian literatur dimulai dengan memasukkan kata kunci di berbagai basis data elektronik dan ditemukan sebanyak 1,043 literatur. Literatur tersebut lalu disaring berdasarkan judulnya untuk menemukan literatur yang sama. Setelah itu, literatur disaring lagi dan dipilih berdasarkan jenis literatur, yaitu artikel jurnal yang sudah melewati proses peer-reviewed dari sepuluh tahun terakhir atau dari tahun 2009, dan didapatkan sebanyak 88 artikel. Pada tahap terakhir, 88 artikel ini kemudian dianalisis abstraknya. Apabila abstrak tidak memberikan 
informasi yang lengkap, dilakukan analisis secara menyeluruh untuk melihat relevansi metode, isi, dan hasil artikel memenuhi kriteria inklusi atau tidak memenuhi. Setelah proses analisis menyeluruh, didapatkan delapan artikel jurnal telah memenuhi kriteria inklusi dan akan diekstraksi datanya. Ekstraksi data ini dilakukan dengan menjabarkan artikel jurnal berdasarkan nama penulis dan tahun terbit, judul, tujuan, ukuran sampel, desain metode, dan alat ukur.

Berdasarkan hasil ekstraksi data dari delapan artikel, diperoleh sebanyak tiga artikel dengan studi kualitatif, tiga artikel dengan studi kuantitatif, dan dua studi dengan desain metode campuran atau mix-method yang dijabarkan sebagai berikut:

1. Penelitian Applequist et al. (2009) di Arizona, Amerika Serikat, yang mengeksplorasi faktor-faktor yang memengaruhi kesuksesan transisi siswa Amerika-Indian dengan disabilitas ringan hingga sedang dari SMA ke jenjang perguruan tinggi dan kesempatan belajar seumur hidup lainnya. Penelitian ini melibatkan 35 siswa keturunan AmerikaIndian di SMA inklusif dengan berbagai macam disabilitas: 19 siswa dengan gangguan belajar, enam siswa dengan gangguan penglihatan, tiga siswa dengan gangguan orthopedic, dua siswa dengan traumatic brain injury, tiga siswa dengan gangguan pendengaran, dan dua siswa dengan gangguan bicara. Penelitian dilakukan dengan metode kualitatif dengan pendekatan longitudinal. Metode yang digunakan mencakup wawancara yang berisi delapan bagian, yaitu informasi umum, pengalaman pendidikan, dukungan dan servis dalam perguruan tinggi, pekerjaan, sejarah keluarga, sosialisasi, locus of control dan kesuksesan. Adapun hasilnya adalah tingkat determinasi diri siswa dengan disabilitas dan tanpa disabilitas berbeda secara signifikan. Hal ini menunjukkan bahwa perencanaan yang berpusat pada siswa dan determinasi diri siswa tidak sepenuhnya direalisasikan untuk penyandang disabilitas. Hal ini dapat dikaitkan dengan kurangnya pemahaman guru tentang determinasi diri dan strategi yang mengembangkan determinasi diri.

2. Penelitian Eisenman et al. (2015) di Newark, Amerika Serikat, yang menganalisis pengalaman siswa tentang determinasi diri sendiri. Penelitian ini menggambarkan perspektif peserta tentang struktur sekolah yang mendukung pengalaman-pengalaman itu dan menyoroti berbagai respons terhadap dukungan belajar dengan model inklusif. Subjek penelitian mencakup 16 siswa kelas 3 SMP inklusi dengan berbagai disabilitas. Sebanyak 9 siswa mengalami gangguan belajar, tiga siswa dengan ADHD, seorang siswa dengan gangguan kesehatan dan tiga siswa dengan disabilitas ganda. Data tambahan pada penelitian ini juga 
didapatkan dari 14 orang tua siswa, sepuluh anggota kelompok belajar, 36 guru, dan 13 konselor. Penelitian ini berjenis kualitatif dengan metode grounded theory. Pengumpulan data dilakukan dengan wawancara semi terstruktur dan focus group discussion yang membahas mengenai pengalaman determinasi diri siswa, peran, dan pengalaman di sekolah, interaksi dengan siswa, kekuatan dan kelemahan sekolah, dan pendekatannya terhadap inklusi. Penelitian ini menemukan adanya tiga fitur yang saling berinteraksi dari dukungan inklusif sekolah yang paling berpengaruh terhadap determinasi diri siswa. Pertama, sekolah menggabungkan struktur spesifik yang menumbuhkan harapan agensi siswa (otonomi). Kedua, agensi siswa didorong oleh orang dewasa yang peduli dan mendukung otonomi di sekolah (hubungan). Ketiga, siswa menerima dukungan dan akomodasi yang terintegrasi (kompetensi).

3. Penelitian Hughes et al. (2013) di New York, Amerika Serikat, yang menguji hubungan antara siswa di sekolah inklusif dan kegiatan masyarakat dan keterampilan determinasi diri dari keterlibatan aktif dalam kegiatan Program Pembelajaran Individu (PPI) dan penggunaan strategi determinasi diri. Penelitian ini melibatkan 47 siswa dari tiga SMA inklusi (A, B, dan C) dengan disabilitas intelektual yang dapat bekerja secara fungsional dalam hal akademis dan keterampilan kerja. Penelitian berjenis kuantitatif dengan metode survei dimana responden mengisi Student SelfDetermination Survey (SS-DS) yang berisi 18 butir dengan 17 butir memiliki pilihan jawaban dan 1 butir pertanyaan terbuka untuk mengukur keterlibatan siswa dalam proses PPI. Hasil penelitian menunjukkan bahwa siswa di sekolah A kurang memiliki determinasi diri dan kurang menggunakan keterampilan determinasi diri daripada siswa di sekolah B dan C yang diberikan banyak peluang di sekolah dan masyarakat $(p<0,01)$. Siswa di sekolah A juga diketahui memiliki sedikit keterlibatan dalam proses pembuatan PPI daripada siswa di sekolah B dan $C(p<0,05)$.

4. Penelitian Shogren et al. (2015) di Kansas, Amerika Serikat, yang menganalisis pengalaman siswa dengan dan tanpa disabilitas yang dididik di sekolah inklusif, mendokumentasikan persepsi mereka tentang budaya sekolah, inklusi, dan praktikpraktik yang diterapkan untuk mendukung semua siswa. Responden penelitian mencakup 86 siswa yang terdiri dari 53 siswa tanpa disabilitas dan 33 siswa dengan disabilitas dari enam sekolah inklusif, lima sekolah dasar dan satu sekolah menengah pertama. Penelitian ini berjenis kualitatif dengan metode focus group discussion. Data dikumpulkan dengan wawancara yang berisi pertanyaan mengenai dukungan guru, kesuksesan siswa, interaksi dengan 
lingkungan, keamanan siswa, relasi dengan keluarga, dan pengalaman di sekolah dengan murid dengan dan tanpa disabilitas.H a s i l penelitian menunjukkan bahwa siswa dengan dan tanpa disabilitas menyebutkan elemen yang membantu determinasi diri dan pengarahan siswa; umpan balik dan pengajaran yang sering; beragam cara representasi, ekspresi, dan keterikatan; dan teknologi. Siswa dengan dan tanpa disabilitas menggambarkan peng-hargaan untuk guru yang mendukung upaya siswa pada pengarahan dan determinasi diri.

5. Penelitian McDougall et al. (2016) di Ontario, Canada, yang menganalisis kualitas hidup atau quality of life (QOL) selama tiga tahun yang depersepsikan secara global pada remaja dengan kondisi kesehatan kronis dan untuk mengidentifikasi faktor pribadi dan lingkungan yang terkait dengan kelompok untuk setiap perspektif. Penelitian ini melibatkan 439 siswa berumur 11-17 tahun dengan berbagai disabilitas dan salah satu dari orang tua mereka berpartisipasi pada baseline, dan sebanyak 302 (69\%) siswa dan orang tuanya menyelesaikan pengumpulan data. Disabilitas siswa antara lain adalah 153 siswa dengan cerebral palsy, 36 siswa dengan spina bifida, 38 siswa dengan autisme, 59 siswa dengan cedera otak yang didapat, 29 siswa dengan keterlambatan perkembangan, 41 siswa dengan sumbing bibir dan atau langit-langit mulut dan 83 siswa dengan kondisi lain (down syndrome, artritis, gangguan komunikasi, amputan, atau gangguan non-progresif lainnya dan gangguan sistem saraf otot atau pusat). Penelitian ini berjenis kuantitatif dengan metode survei. Data dikumpulkan dengan Student Life Satisfaction Scale (SLSS) dengan 6 butir skala Likert dari 1 (sangat tidak setuju) hingga 6 (sangat setuju) dan SelfDetermination Scale yang diadaptasi dari Arc's Self-Determination Scale. Hasil penelitian menunjukkan bahwa siswa yang memiliki tingkat yang tinggi dalam determinasi diri, spiritualitas, dukungan keluarga dan sosial, fungsi keluarga, produktivitas sekolah atau keterikatan, dan rasa kepemilikan atau keamanan sekolah me-miliki kemungkinan yang kecil untuk berada di kelompok dengan tingkat kualitas hidup yang sedang atau rendah dan begitu pula sebaliknya $(p<0,0001)$.

6. Penelitian Duttlinger et al. (2012) di Georgia, Amerika Serikat, yang menguji kegiatan instruksi dari pembuatan jadwal kegiatan gambar atau picture activity schedules (PASs) atau penggunaan dukungan berbasis gambar menggunakan dukungan dan penyelesaian serangkaian arahan verbal dan mengetahui bagaimana siswa dengan gangguan intelektual di empat sekolah menengah pertama menggunakannya untuk menyelesaikan tugas secara mandiri. Penelitian ini melibatkan empat siswa SMP yang berusia 
13-14 tahun dengan gangguan inelektual. Penelitian ini berjenis kuantitatif dengan metode eksperimen. Observasi dilakukan oleh guru untuk melihat kemampuan peserta untuk secara mandiri membaca simbol gambar yang terkait dengan target tugas dan menyelesaikan tugas. Guru mengum-pulkan data validitas sosial dengan menyurvei para profesional yang terlibat langsung dengan peserta, seperti guru pendidikan khusus, dua paraprofesional pendidikan khusus dan ahli patologi wicara-bahasa yang mengamati sesi eksperimen lalu mengisi kuesioner menggunakan skala Likert dari 1 (sangat tidak setuju) hingga 5 (sangat setuju). Data validitas sosial tambahan dikumpulkan dengan menyurvei peserta penelitian. Setiap peserta mengisi kuesioner menggunakan skala Likert yang berkisar dari 1 (saya tidak setuju) hingga 3 (saya sangat setuju). Hasil penelitian menunjukkan semua peserta memperlihatkan peningkatan kemampuan untuk menyelesaikan urutan tiga atau lima tugas mengikuti arahan verbal saat menggunakan PAS dibanding-kan dengan kondisi tidak adanya PAS yang digunakan. Hal ini meunjukkan bahwa meningkatkan fungsi independen individu dengan gangguan intelektual dan mengurangi keter-gantungan dengan yang lain berpotensi mening-katkan determinasi diri.
7. Penelitian Jessup et al. (2018) di Sydney, Australia, yang menganalisis inklusi sosial pada siswa di sekolah menengah atas Australia dengan gangguan penglihatan. Penelitian ini ingin memahami bagaimana siswa menggambarkan inklusi sosial di sekolah, dari apa yang siswa rasakan hingga faktor yang memengaruhi persepsi siswa. Responden penelitian ini adalah dua belas siswa SMA yang berusia 13-17 tahun dengan gangguan penglihatan. Penelitian ini termasuk mixmethods dimana metode kualitatif dilakukan dengan wawancara, dan metode kuantitatif dengan metode survei.

Wawancara semi terstruktur dilakukan untuk mengetahui aspek sosial dari sekolah dan The Psychological Sense of School Membership (PSSM), yaitu sebuah laporan pribadi untuk mengukur rasa kepemilikan siswa terhadap sekolah yang berisi 18 butir dan menggunakan 5 poin skala Likert. Hasilnya menunjukkan bahwa pengaruh konteks sosial sekolah dalam determinasi diri siswa adalah strategi untuk mengembangkan hub-ungan dan meningkatkan inklusi sosial, upaya orang lain untuk membangun hubungan dengan siswa, memiliki kendali atas keputusan dan pem-belajaran, memiliki tem-pat untuk sukses dan diakui oleh orang lain, dan pengecualian atau peno-lakan teman sebaya sebagai pengalaman se-kolah yang paling menyakitkan. 
8. Penelitian Washington et al. (2012) di Nashville, Amerika Serikat, yang membandingkan keterlibatan dalam perencanaan pendidikan dan peng-gunaan strategi determinasi diri pada dua kelompok siswa sekolah menengah atas untuk siswa dengan status sosial ekonomi yang rendah dan sebagian besar berkulit hitam. Terdapat 39 responden pada penelitian ini yang terdiri dari 19 siswa dengan gangguan intelektual parah yang berusia 14-21 tahun dan 20 siswa tahun terakhir yang dianggap sukses. Penelitian dilakukan dengan mixmethods, dimanaa aspek kualitatif dilakukan dengan wawancara, dan aspek kuantitatif dengan metode survei. Survei dilakukan dengan Student Self-Determination Survey (SS-DS) yang berisi 20 butir pertanyaan dengan pilihan jawaban dan permintaan pemberian contoh mengenai keterlibatan dalam PPI, penggunaan strategi determinasi diri dan pembuatan keputusan pribadi. Skala lain yang digunakan adalah The Arc's Self-Determination Scale (SDS) dan Skala Pemberdayaan Psikologis - Versi Remaja. Skala ini digunakan sebagai pengukuran kedua determinasi diri siswa yang terdiri dari 16 pertanyaan yang dirancang untuk menilai keper-cayaan siswa dalam kemampuannya, persepsi tentang kontrol, dan harapan akan kesuksesan. Hasil penelitian menunjukkan bahwa siswa dengan disabilitas dalam pendidikan khusus berpartisipasi dalam kegiatan yang lebih sedikit, seperti di kelas pendidikan umum atau karier, kegiatan transisi, atau pekerjaan dalam setiap hari di luar kelas pendidikan khusus. Siswa dengan disabilitas jauh lebih kecil kemungkinannya terlibat dalam kegiatan perencanaan pendidikan atau penggunaan strategi deter-minasi diri daripada siswa tanpa disabilitas di pendidikan umum.

\section{Pembahasan}

Penelitian ini bertujuan mengungkap gambaran tentang keadaan, hasil, faktor, dan strategi peningkatan determinasi diri siswa di sekolah inklusi secara sistematis dan sintesis. Berdasarkan hasil ekstraksi data dari semua artikel, ditemukan bahwa terdapat empat tema yang akan dibahas pada analisis, yaitu: (1) Keadaan atau pengalaman determinasi diri siswa dengan dan tanpa kebutuhan khusus di sekolah inklusi; (2) Hasil atau efek dari determinasi diri siswa; (3) Faktor yang memengaruhi determinasi diri siswa; dan (4) Strategi untuk meningkatkan determinasi diri siswa di sekolah inklusi.

\section{Keadaan determinasi diri siswa}

Keadaan tingkat determinasi diri siswa pada sekolah inklusi memiliki perbedaan yang signifikan antara siswa berkebutuhan khusus dan siswa tanpa kebutuhan khusus. Penelitian Washington et al. (2011), Applequist et al. (2009), dan Hughes et al. (2013) mengungkapkan bahwa siswa dengan kebutuhan khusus memiliki tingkat partisipasi 
yang rendah pada penyusunan Program Pembelajaran Individu (PPI). Sebaliknya, siswa tanpa kebutuhan khusus yang menerima pendidikan umum memiliki partisipasi yang lebih besar di kegiatan perencanaan pendidikan, seperti berdiskusi dengan konselor mengenai jadwal, nilai dan rencana setelah sekolah, membuat tujuan yang harus dicapai, mengevaluasi perkembangan diri selama di sekolah setiap minggunya, dan mendiskusikan tujuan akademik dengan orang tua dan keluarga.

Siswa berkebutuhan khusus lebih jarang menggunakan keterampilan determinasi diri daripada siswa tanpa kebutuhan khusus di sekolah inklusi. Siswa berkebutuhan khusus jarang menetapkan tujuan di sekolah, kurang mampu memilih atau mengambil keputusan sendiri, jarang memberikan penguatan terhadap diri sendiri (self-reinforcing), tidak menerapkan instruksi diri dan kurang bisa menyelesaikan masalah sendiri. Namun demikian, siswa dapat membela diri dalam situasi sosial atau dari intimidasi dan dapat menyuarakan pendapat mereka (Washington et al., 2011). Temuan ini sesuai dengan penelitian Tichá et al. (2018) dan Kurth et al. (2015) yang juga menyatakan bahwa siswa berkebutuhan khusus memiliki determinasi diri yang kurang, tidak seperti siswa tanpa kebutuhan khusus yang lebih memiliki peluang dan kesempatan untuk menggunakan kemampuan determinasi diri di sekolah. Saat peristiwa sehari-hari dapat diprediksi, kurangnya tantangan dan beragam rangsangan yang harus ditanggapi, siswa kemungkinan besar tidak belajar perilaku determinasi diri seperti melatih preferensi atau menetapkan tujuan.

\section{Hasil atau efek determinasi diri}

Berdasarkan penelitian McDougall et al. (2016) tentang efek atau hasil dari determinasi diri siswa, siswa yang memiliki determinasi diri yang tinggi terutama dalam hal orientasi tujuan juga akan memiliki kualitas hidup yang baik. Semua siswa mendapat manfaat dari keterampilan determinasi diri akan meningkatkan otonomi dan kemampuan mengatur diri mereka sendiri (Wehmeyer et al., 1996). Saat siswa memiliki determinasi diri, maka kualitas hidup mereka akan meningkat (Wehmeyer \& Schalock, 2000).

Siswa yang memiliki kualitas hidup yang baik tidak memiliki (a) masalah emosional, (b) memiliki tingkat spiritualitas yang tinggi, (c) mendapatkan dukungan keluarga yang baik, (d) memiliki produktivitas serta keterikatan sekolah, (e) rasa memiliki dan rasa aman di sekolah, serta (f) banyak peluang di rumah dan komunitas. Sementara itu, siswa dengan determinasi diri yang rendah sangat berpeluang untuk (a) memiliki kualitas hidup yang buruk yang ditandai dengan masalah emosional dan spiritualitas, (b) keluarga yang kurang mendukung, (c) kurangnya produktivitas, (d) keterikatan dan rasa aman di sekolah, serta (e) menerima banyak hambatan di sekolah dan masyarakat (McDougall et al, 2016). 


\section{Faktor determinasi diri siswa}

Salah satu faktor yang memengaruhi determinasi diri siswa adalah peran guru, sebagaimana yang dijelaskan oleh Applequist et al. (2009) dan Shogren et al. (2015), siswa merasa dukungan keluarga dan guru-guru sekolah dalam mencapai tujuan lebih berharga daripada sekolah inklusi itu sendiri. Guru memainkan peran penting dalam membimbing siswa dan berkontribusi pada kesuksesan mereka. Siswa mengindikasikan bahwa guru biasanya mendukung dengan menawarkan dorongan dan dukungan moral. Selain menunjukkan minat pada siswa dan bersikap mendukung, guru siswa berkebutuhan khusus dapat memberikan informasi spesifik kepada siswa, sehingga mereka dapat berhasil di sekolah dan mempersiapkan diri untuk pendidikan selanjutnya atau lingkungan kerja (Applequist, et al, 2009). Siswa berkebutuhan khusus merasa terlibat dan dijadikan bagian dari sekolah oleh para guru yang menyeimbangkan harapan yang tinggi, memberikan dukungan, dan bersikap baik. Siswa belajar untuk mengetahui bagaimana melakukan sesuatu oleh dirinya sendiri dari tantangan yang diberikan guru dan kesempatan terlibat dalam hal yang sulit Shogren et al. (2015). McDougall et al. (2016) dan Applequist et al. (2009) menjelaskan bahwa selain guru, keluarga juga harus mendukung dan membantu siswa untuk mencapai tujuan mereka dan harus lebih terlibat penuh dalam proses transisi dari sekolah.
Penelitian Hughes et al. (2013), Eisenman et al. (2015), dan Jessup et al. (2018) menunjukkan bahwa faktor sekolah juga memengaruhi tingkat determinasi diri siswa. Hughes et al. (2013) menemukan bahwa sekolah inklusi yang memiliki sumber daya dan pengalaman yang kurang untuk memperkaya pengalaman siswa membuat keterampilan determinasi diri siswa cenderung terhambat, terutama bila sekolah berada di lingkungan dengan tingkat kemiskinan yang tinggi. Bila siswa berkebutuhan khusus memiliki akses yang terbatas di sekolah dan masyarakat, seperti contohnya terus berada di kelas khusus atau terpisah dengan teman yang tidak memiliki kebutuhan khusus, hal ini akan merugikan siswa. Siswa cenderung tidak mengalami perkembangan dalam keterampilan determinasi diri. Siswa jadi kurang bisa membela diri, membuat pilihan, memperkuat diri sendiri, memonitor diri sendiri, mengevaluasi diri sendiri dan memecahkan masalah dibandingkan dengan teman sebayanya yang memiliki lebih banyak peluang dalam pendidikan inklusif. Ketika kegiatan sehari-hari telah benar-benar dapat diprediksi, siswa kemungkinan tidak memiliki kesempatan untuk mengembangkan keterampilan menghadapi peristiwa dan tantangan yang terus berubah dan tidak bisa diprediksi di sekolah maupun komunitas.

Hasil penelitian Eisenman et al. (2015) menunjukkan bahwa pengalaman siswa dalam mengembangkan determinasi diri terkait 
dengan pembinaan yang mereka terima pada advokasi diri, organisasi, dan praktik pemantauan tujuan. Praktik-praktik ini menyatu dalam interaksi dengan wali kelas, diperkuat di kelas dan les setelah sekolah, serta difasilitasi oleh dukungan akademik yang terintegrasi dan diimplementasikan lintas kelas. Selanjutnya, pengalaman siswa dengan guru yang mendukung otonomi dan keberhasilan akademis di antara teman sebaya yang tidak berkebutuhan khusus akan meningkatkan rasa efikasi diri siswa berkebutuhan khusus. Struktur sekolah inklusi telah meningkatkan determinasi diri dan keterikatan siswa dalam kurikulum yang menantang dan memperluas pilihan untuk melanjutkan pendidikan di perguruan tinggi dan karier.

Penelitian Jessup et al. (2018) membahas mengenai konteks hubungan sosial di sekolah yang akan memengaruhi determinasi diri siswa. Dalam praktiknya, ini akan membutuhkan staf sekolah untuk fokus pada siswa berkebutuhan khusus supaya mengeksplorasi dan membangun kekuatan, sepenuhnya mengakses kurikulum bersama teman sebayanya, dan punya waktu dan kesempatan untuk mengembangkan persahabatan dengan teman sebaya. Tingkat inklusi sosial peserta meningkat ketika tiga kebutuhan ini dipenuhi. Dari sini bisa disimpulkan bahwa konteks sosial yang mendorong determinasi diri juga mendorong inklusi sosial.

\section{Strategi peningkatan determinasi diri siswa}

Strategi yang dapat mendorong determinasi diri siswa, sebagaimana dijelaskan oleh Shogren et al. (2015) dan Duttlinger et al. (2012) dari sisi akademik, yaitu strategi belajar. Shogren et al. (2015) menemukan siswa dengan dan tanpa kebutuhan khusus menikmati strategi pembelajaran yang menyediakan banyak cara untuk belajar dan terlibat dalam materi. Siswa tanpa kebutuhan khusus mengatakan bahwa kegiatan yang menarik membuat mereka merasa lebih bersemangat belajar. Siswa menggambarkan manfaat dari penerapan praktik berbasis bukti di kelas, termasuk sistem (a) pemantauan kelas, (b) strategi untuk mempromosikan determinasi diri, (c) pengajaran ulang dan penilaian yang sering, (d) berbagai cara representasi, (e) ekspresi, dan (f) keterikatan. Siswa dengan dan tanpa kebutuhan khusus menegaskan bahwa mereka ingin menjadi pembelajar yang memiliki determinasi diri, harapan yang tinggi, dan didukung untuk sukses.

Penelitian Duttlinger et al. (2012) menjelaskan bahwa penggunaan strategi PAS (Picture Activity Schedule), yaitu penggunaan dukungan berbasis gambar menggunakan dukungan dan penyelesaian serangkaian arahan verbal, membuktikan bahwa simbol gambar adalah intervensi yang efektif untuk meningkatkan perkembangan pekerjaan, akademik, dan keterampilan hidup sehari-hari. Siswa menunjukkan perubahan langsung dan 
menunjukkan hubungan fungsional antara kondisi saat belajar tanpa dukungan gambar dan saat ada dukungan gambar. Siswa tidak hanya menunjukkan peningkatan kemampuan untuk menyelesaikan tugas yang ditetapkan mengikuti arahan verbal, tetapi juga menyelesaikan tugas-tugas tersebut sesuai dengan urutannya. Hal ini didasarkan pada peningkatan pembelajaran pengelolaan diri dan kemandirian. Strategi ini juga menggambarkan fleksibilitas yang lebih besar pada cara guru dalam menetapkan tugas. Penggunaan PAS dapat membantu siswa berkebutuhan khusus dalam mengatur diri sendiri dan tugas seharihari yang akan meningkatkan kemandirian dan mengurangi ketergantungan pada orang lain. Penguatan keterampilan manajemen diri siswa adalah sebuah langkah untuk menjadi individu yang lebih mandiri.

$$
\text { Berkaitan dengan strategi }
$$
pengembangan determinasi diri siswa dari aspek sekolah dan konteks sosial di sekolah, Hughes et al. (2013) menjelaskan bahwa sekolah perlu meningkatkan inklusivitas dan pengalaman yang tersedia bagi siswa berkebutuhan khusus untuk mendorong determinasi diri dan keberhasilan pascasekolah. Hal ini terutama berlaku untuk siswa yang ada di sekolah-sekolah dengan fasilitas minimal yang memiliki keterbatasan peluang di sekolah dan komunitas. Selain itu, sekolah perlu mengajarkan dan mendukung siswa dalam memperoleh keterampilan partisipasi dalam PPI. Seperti yang dikemukakan oleh Shogren et al. (2007), sekolah perlu menyediakan kesempatan, tantangan, instruksi, dan dukungan bagi siswa yang memiliki kesempatan terbatas untuk belajar berlatih determinasi diri dan keterampilan perencanaan pendidikan. Siswa dapat belajar membuat pilihan, mengadvokasi diri, dan mengarahkan kinerja mereka sendiri (Wehmeyer et al, 2007).

Dalam konteks sosial di sekolah, strategi yang diusulkan oleh Jessup et al. (2018) adalah guru perlu mengetahui dan memperhatikan masing-masing siswa berkebutuhan khusus untuk memastikan bahwa konten pelajaran dan pedagogi dapat diakses oleh siswa untuk membuktikan bahwa kebutuhan pembelajaran mereka tidak diabaikan. Saat siswa merasa kesulitan untuk memegang kendali atau untuk sukses dalam pelajaran saat dibatasi, guru dapat mengizinkan siswa dan temannya berpartisipasi dalam kegiatan alternatif, bukannya mengisolasi siswa. Oleh sebab itu, untuk mengakomodasi beragam peserta didik, struktur sekolah mungkin perlu diubah.

Perubahan seperti itu akan memungkinkan sekolah untuk memperluas fokus mereka menjadi lebih fleksibel, berpusat pada siswa, dan holistik. Selain itu, keterampilan interaksi sosial juga sangat penting dalam memungkinkan siswa berkebutuhan khusus menempatkan diri mereka. Guru perlu memberikan siswa strategi untuk mengambil inisiatif atau mengedepankan diri mereka sendiri dan 
mendorong siswa untuk berusaha dalam persahabatan karena siswa yang sukses akan lebih terlibat secara sosial. Namun demikian, agar memiliki tempat untuk sukses, siswa membutuhkan peluang untuk mengeksplorasi dan mengidentifikasi kekuatan dan kemampuan mereka. Staf sekolah seharusnya mampu memfasilitasi peluang agar kekuatan siswa dapat diidentifikasi dan dikembangkan (Jessup et al., 2018).

Hasil penelitian ini berimplikasi pada sumbangan informasi dari berbagai penelitan berbasis bukti mengenai keadaan, hasil, faktor, dan strategi untuk meningkatkan determinasi diri siswa di sekolah inklusi. Berdasarkan informasi tersebut diharapkan penelitian bertambah banyak di bidang pendidikan khusus, yakni tentang siswa berkebutuhan khusus dan determinasi diri, terutama pada masalah strategi untuk mengoptimalkan pembelajaran siswa melalui determinasi diri. Hasil penelitian yang sudah dipaparkan dapat digunakan untuk mengajarkan siswa tentang independensi. Strategi yang dipaparkan juga memiliki implikasi pada lingkungan rumah, sekolah, dan pekerjaan. Temuan-temuan dari penelitian sebelumnya dapat digunakan untuk memberikan siswa berkebutuhan khusus alat yang efektif untuk mengatur tugas dan berlatih menjadi individu yang memiliki determinasi diri. Pada akhirnya, siswa tidak hanya memperoleh kemandirian dengan mempelajari cara mengambil keputusan, berinteraksi, menyusun, dan mengelola tugas, tetapi siswa memiliki perasaan positif tentang kemampuannya yang mandiri dan siswa bisa menyelesaikan serangkaian tugas tanpa intervensi atau bimbingan orang dewasa.

Adapun beberapa keterbatasan penelitian ini antara lain, penelitian ini dilakukan dengan memulai pencarian literatur melalui enam basis data daring sesuai dengan topik yang dipilih, sehingga masih banyak artikel jurnal di beberapa basis data lain yang belum teridentifikasi. Penelitian ini juga menggunakan kata kunci yang sama untuk mencari artikel di setiap basis data. Meskipun peneliti sudah memilih kata kunci yang dianggap paling baik, tidak menutup kemungkinan bahwa terdapat kata kunci lain yang lebih tepat untuk mencari artikel mengenai determinasi diri siswa di sekolah inklusi yang berbeda di setiap basis data.

Peneliti juga tidak membatasi penelitian ini berdasarkan lokasi demografis dan tidak menentukan jenis kebutuhan khusus siswa, sehingga hasil penelitian yang dijabarkan kurang spesifik. Penelitian ini dilakukan hanya oleh penulis, padahal idealnya jenis penelitian tinjauan sistematis sebaiknya dilakukan oleh lebih banyak orang untuk menghindari bias. Aspek-aspek tertentu dari tinjauan sistematis, seperti keputusan kriteria inklusi dan pengkodean data, seharusnya dilakukan secara independen oleh lebih dari satu orang atau oleh tim (White \& Waddington, 2012). Namun, pemeriksaan menyeluruh telah dilakukan dalam memilih artikel dan terbatas pada artikel yang sudah melalui proses peer-reviewed, 
sehingga kualitas dan kredibilitas artikel yang diteliti dapat dijaga.

\section{Simpulan}

Sebagaimana tujuan penelitian ini, melalui tinjauan sistematik dicapai beberapa kesimpulan tentang keadaan, hasil, faktor, dan strategi peningkatan determinasi diri siswa di sekolah. Keadaan tingkat determinasi diri siswa pada sekolah inklusi menunjukkan perbedaan antara siswa berkebutuhan khusus dan siswa tanpa kebutuhan khusus, terutama pada sekolah dengan tingkat sosial ekonomi yang rendah. Siswa berkebutuhan khusus umumnya tidak diikutsertakan dalam pembuatan rencana belajar dan kurang memiliki peluang untuk menentukan keputusan dan kesempatan untuk berinteraksi dengan masyarakat. Sebaliknya, siswa tanpa kebutuhan khusus memiliki partisipasi yang lebih besar. Terkait dengan hasil atau efek dari determinasi diri, siswa yang memiliki determinasi diri yang tinggi akan memiliki kualitas hidup yang baik dan begitu pula sebaliknya.

Beberapa faktor penting dalam menentukan determinasi diri siswa adalah peran guru dan keluarga, faktor sekolah, dan konteks sosial di sekolah. Guru dan keluarga berperan dalam memberikan dukungan, harapan dan tantangan untuk mencapai tujuan siswa. Sekolah harus bisa dengan bijak mengelola sumber daya dan akses untuk memperkaya pengalaman siswa dalam berinteraksi dan melatih keterampilan determinasi dirinya. Staf sekolah dan teman sebaya juga harus diikutsertakan dalam mengembangkan kemampuan berinteraksi siswa. Strategi belajar yang menyediakan banyak cara menarik untuk terlibat dalam materi seperti praktik berbasis bukti dan dukungan berbasis gambar dapat diterapkan untuk membangun determinasi diri siswa. Sekolah juga perlu menyediakan kesempatan, tantangan, instruksi, dan dukungan bagi siswa yang memiliki kesempatan terbatas untuk belajar menggunakan keterampilan determinasi diri dalam proses pembelajaran.

\section{Saran}

Berdasarkan keterbatasan penelitian ini, rekomendasi untuk penelitian-penelitian mendatang adalah bahwa peneliti selanjutnya perlu mengidentifikasi hasil penelitian mengenai determinasi diri siswa khususnya di Indonesia. Hal itu disebabkan masih kurangnya penelitian tentang determinasi diri siswa pada sekolah inklusi di wilayah Asia, terutama Asia Tenggara. Penelitian semacam itu semakin diperlukan mengingat adanya perbedaan karakteristik siswa dan sistem sekolah inklusi di Indonesia dan negara-negara lain. Penelitian selanjutnya juga dapat mendeskripsikan determinasi diri siswa di sekolah inklusi dengan mengategorisasikan kebutuhan khusus siswa, sehingga didapatkan data mengenai gambaran tingkat atau pengalaman determinasi diri siswa pada setiap kebutuhan 
khusus. Begitu pula peneliti-peneliti yang akan datang dapat mengeksplorasi determinasi diri guru dan sumber daya masyarakat lain yang berpengaruh di sekolah inklusi untuk mendapatkan pemetaan determinasi diri antar individu di sekolah inklusi.

\section{Referensi}

Applequist, K. L., Mears, R., \& Loyless, R. (2009). Factors influencing transition for students with disabilities: The American Indian experience. International Journal of Special Education, 24, 45-56. https:// www.researchgate.net/publication/ $\begin{array}{llllllllll}2 & 8 & 6 & 9 & 7 & 9 & 7 & 5 & 3 & -\end{array}$ Factors_influencing_transition for_students_with_disabilities The_American_Indian_experience

Èablová, L., Pates, R., Miovský, M., \& Noel, J. (2017). How to write a systematic review article and meta-analysis. In T. . F. Babor, K. Stenius, R. Pates, M. Miovský, J. O'Reilly, \& P. Candon (Eds.), Publishing addiction science: A guide for the perplexed (pp. 173-189). Ubiquity Press. https://doi.org/10.5334/bbdi.

Cobb, B., Lehmann, J., Newman-Gonchar, R., \& Alwell, M. (2009). Self-determination for students with disabilities: A narrative metasynthesis. Career Development for Exceptional Individuals, 32, 108-114. h t tps://doi.org/10.117 / / 0885728809336654

Duttlinger, C., Ayres, K., Bevill-Davis, A., \& Douglas, K. (2012). The effects of a picture activity schedule for students with intellectual disability to complete a sequence of tasks following verbal directions. Focus on Autism and Other Developmental Disabilities, 28(1), 32-43. h t tp s: / / do i.org / 10.1177 / 1088357612460572

Eisenman, L., Pell, M., Poudel, B., \& Pleet-Odle, A. (2015). I think i'm reaching my potential. Career Development and
Transition for Exceptional Individuals, 38(2), 101-112. https://doi.org/ $10.1177 / 2165143414537349$

Fowler, C., Konrad, M., Walker, A., Test, D., \& Wood, W. (2007). Self-determination interventions' effects on the academic performance of students with developmental disabilities. Education and Training in Developmental Disabilities, 42(3), 270-285. https://www.jstor.org/ stable/23879622

Hughes, C., Cosgriff, J., Agran, M., \& Washington, B. (2013). Student Self-Determination: A Preliminary investigation of the role of participation in inclusive settings. Education and Training in Autism and Developmental Disabilitites, 48(1), 3-17. https://www.jstor.org/stable/23879882

Jessup, G., Bundy, A., Hancock, N., \& Broom, A. (2018). Being noticed for the way you are: Social inclusion and high school students with vision impairment. British Journal of Visual Impairment, 36(1), 90103. https://doi.org/10.1177/ 0264619616686396

Konrad, M., Fowler, C., Walker, A., Test, D., \& Wood, W. (2007). Effects of selfdetermination interventions on the academic skills of students with learning disabilities. Learning Disability Quarterly, 30(2), 89-113. https://doi.org/10.2307/ 30035545

Kurth, J., Lyon, K., \& Shogren, K. (2015). Supporting students with severe disabilities in inclusive schools: A descriptive account from schools implementing inclusive practices. Research and Practice for Persons with Severe Disabilities, 40(4), 261-274. h t tp s: / / doi.org / 10.1177 / 1540796915594160

Lachapelle, Y., Wehmeyer, M., Haelewyck, M., Courbois, Y., Keith, K., Schalock, R., Verdugo, M., \& Walsh, P. (2005). The relationship between quality of life and self-determination: An international study. Journal of Intellectual Disability Research, 49(10), 740-744. https:// 
do i.org/ $10.1111 /$ j. 1365 2788.2005.00743.x

Lee, S. H., Wehmeyer, M., Soukup, J., \& Palmer, S. (2010). Impact of curriculum modifications on access to the general education curriculum for students with disabilities. Exceptional Children, 76(2), 213-233. https://doi.org/10.1177/ 001440291007600205

Legault, L., \& Inzlicht, M. (2013). Selfdetermination, self-regulation, and the brain: Autonomy improves performance by enhancing neuroaffective responsiveness to selfregulation failure. Journal of Personality and Social Psychologyocial Psychology, 105, 123-138. https://doi.org/ $10.1037 / \mathrm{a} 0030426$

Littell, J. H., Corcoran, J., \& Pillai, V. (2008). Systematic reviews and meta-analysis. Oxford University Press, Inc.

McDougall, J., DeWit, D., Nichols, M., Miller, L., \& Wright, F. . (2016). Three-year trajectories of global perceived quality of life for youth with chronic health conditions. Quality of Life Research, 25(12), 3157-3171. https://doi.org/ 10.1007/s11136-016-1353-z

Nota, L., Ferrari, L., Soresi, S., \& Wehmeyer, M. (2007). Self-determination, social abilities and the quality of life of people with intellectual disability. Journal of Intellectual Disability Research, 51(11), 850-865. https://doi.org/10.1111/ j.1365-2788.2006.00939.x

Petticrew, M., \& Roberts, H. (2006). Systematic reviews in the social sciences: A practical guide. Blackwell Publishing Ltd. https://doi.org/10.1002/ 9780470754887

Seong, Y., Wehmeyer, M. L., Palmer, S. B., \& Little, T. D. (2015). Effects of the self-directed individualized education program on self-determination and transition of adolescents with disabilities. Career Development and Transition for Exceptional Individuals, 38(3), 132-141. h t t p s : / / d o i . o r g / 10.1177\%2F2165143414544359

Seong, Y., Wehmeyer, M., Shogren, K., Palmer, S., \& Little, T. (2019). Examining underlying relationships between the ASDA-S and the AIR and the ASDA of adolescents and young adults with and without disabilities. Advances in Neurodevelopmental Disorders, 3(2), 173187. https://doi.org/10.1007/s41252019-00101-5

Shogren, K. A. (2013). Self-determination and transition planning. Brookes.

Shogren, K., Gross, J., Forber-Pratt, A., Francis, G., Satter, A., Blue-Banning, M., \& Hill, C. (2015). The perspectives of students with and without disabilities on inclusive schools. Research and Practice for Persons with Severe Disabilities, 40(4), 243-260. https://doi.org/10.1177/ 1540796915583493

Shogren, K., Lopez, S., Wehmeyer, M., Little, T., \& Pressgrove, C. (2006). The role of positive psychology constructs in predicting life satisfaction in adolescents with and without cognitive disabilities: An exploratory study. The Journal of Positive Psychology, 1, 37-52. https:// doi.org/10.1080/17439760500373174

Shogren, K., Wehmeyer, M., Palmer, S., Rifenbark, G., \& Little, T. (2015). Relationships between selfdetermination and postschool outcomes for youth with disabilities. The Journal of Special Education, 48(4), 256-267. ht tps://doi.org/10.117 7/ 0022466913489733

Shogren, K., Wehmeyer, M., Palmer, S., Soukup, J., Little, T., Garner, N., \& Lawrence, M. (2007). Examining individual and ecological predictors of the selfdetermination of students with disabilities. Exceptional Children, 73, 488-509. https://doi.org/10.1177/ 001440290707300406

Siddaway, A., Wood, A., \& Hedges, L. (2019). How to do a systematic review: A best 
practice guide for conducting and reporting narrative reviews, metaanalyses, and meta-syntheses. Annual Review of Psychology, 70(1), 747-760. https://doi.org/10.1146/annurevpsych-010418-102803

Test, D. W., Fowler, C. H., Richter, S. M., White, J., Mazzotti, V., Walker, A. R., \& Kortering, L. (2009). Evidence-based practices in secondary transition. Career Developmentfor Exceptional Individuals, 32, 115-128. https:/ /doi.org/10.1177/0885728809346960

Tichá, R., Abery, B., Johnstone, C., Poghosyan, A., \& Hunt, P. (Eds. . (2018). Inclusive education strategies: A textbook. University of Minnesota; Yerevan, Armenia: UNICEF Armenia \& Armenian State Pedagogical University.

Walker, H., Calkins, C., Wehmeyer, M. L., Walker, L., Bacon, A., Palmer, S. B., Jesien, G. S., Nygren, M. A., Heller, T., Gotto, G. S., Abery, B. H., \& Johnson, D. R. (2011). A socialecological approach to promote selfdetermination. Exceptionality, 19(1), 618. https://doi.org/10.1080/ 09362835.2011.537220

Washington, B., Hughes, C., \& Cosgriff, J. (2011). High-poverty youth: Self-determination and involvement in educational planning. Career Development and Transition for Exceptional Individuals, 35(1), 14-28. h t tp s : / / do i.org / 10.1177 / 0885728811420135

Wehmeyer, M. L. (2005). Self-determination and individuals with severe disabilities: Re-examining meanings and misinterpretations. Research and Practice for Persons with Severe Disabilities, 30(3), 113-120. https:// doi.org/10.2511/rpsd.30.3.113

Wehmeyer, M. L., Agran, M., Hughes, C., Martin, J. E., Mithaug, D. E., \& Palmer, S. B. (2007).
Promoting self-determination in students with developmental disabilities. Guilford.

Wehmeyer, M. L., \& Field, S. L. (2007). Selfdetermination: Instructional and assessment strategies. Corwin Press.

Wehmeyer, M. L., Kelchner, K., \& Richards, S. (1996). Essential characteristics of selfdetermined behavior of individuals with mental retardation. American Journal of Mental Retardation, 100(6), 632-642. https://pubmed.ncbi.nlm.nih.gov/ 8735576/

Wehmeyer, M. L., \& Little, T. D. (2013). Selfdetermination. In M. L. Wehmeyer (Ed), The Oxford handbook of positive psychology and disability (pp.116-136). Oxford University Press. https://doi.org/ $10.1093 /$ o x f o r d h b / 9780195398786.001.0001

Wehmeyer, M. L., \& Schalock, R. (2000). Selfdetermination and quality of life: Implications for special education services and supports. Focus on Exceptional Children, 33(8), 1-16. https: / / doi.org/10.17161/ fec.v33i8.6782

Weinstein, N., \& Ryan, R. M. (2011). A Selfdetermination theory approach to understanding stress incursion and responses. Stress and Health, 27(1), 417. https://doi.org/10.1002/smi.1368

White, H., \& Waddington, H. (2012). Why do we care about evidence synthesis? An introduction to the special issue on systematic reviews. Journal of Development Effectiveness, 4(3), 351-358. https:// doi.org/10.1080/19439342.2012.711343

Received 8 October 2019 Revised 30 May 2020 Accepted 30 May 2020 